\title{
RECENT DEVELOPMENTS IN ITALIAN CONSTITUTIONAL-CRIMINAL LAW
}

\section{ALBERTO CADOPPI*}

This article compares Italian "ConstitutionalCriminal" law under Italy's Constitution with the development of legal rights in Canada under the Canadian Charter of Rights and Freedoms. The author explains the "constitutional approach" to criminal law in Italy, which is a complex web of principles which govern the criminal law by defining the concepts of "crime" and "criminal responsibility". Professor Cadoppi then examines various aspects of "constitutional-criminal" law as it has been developed by legal scholars, and the extent to which this approach has been accepted by the Italian Constitutional Court. The legal rights found in "constitutional-criminal" law are thought to be extendable to Canadian constitutional law, given the broad language of section 7 of the Canadian Charter of Rights. The author notes that the Supreme Court of Canada has given the Canadian Charter an expansive interpretation comparable to the Italian "constitutional-criminal" law approach, and uses this parallel to show that Canadian and Italian courts are moving roward a vision of a new criminal law in which "fundamental justice" will prevail.
Cet article compare le droit "constitutionnelcriminel" relevant de la Constitution italienne au développement des droits reconnus par la Charte canadienne des droits et libertés. L'auteur définit quelle est "l'approche constitutionnelle" envers le droit pénal en Italie - un réseau complexe de principes qui gouvernent le droit criminel en définissant les concepts $d$ "infraction pénale" et de "responsabilité pénale". Le Professeur Cadoppi examine ensuite les divers aspects du droit "constitutionnel-criminel" tel que l'ont développé les juristes, et note jusqu'à quel point cette approche a été acceptée par les tribunaux constitutionnels italiens. Il estime que les droits garantis par le droit "constitutionnel-criminel" pourraient s'appliquer au droit constitutionnel canadien, compte tenu de la phraséologie très générale de l'article 7 de la Charte canadienne des droits et libertés. L'auteur relève que la Cour suprême du Canada a donné d la Charte canadienne une interprétation large comparable d l'approche de l'thalie envers le droit "constitutionnel-criminel": il utilise ce parallèle pour démontrer que les tribunaux canadiens et italiens évoluent vers une vision d'un droit criminel nouveau ou prévaut la notion de "justice fondamentale."

* Professor, University of Trento, Italy. I must thank Professor Bruce Ziff, University of Alberta, Edmonton, Alberta, for his helpful assistance in preparing this paper. 


\section{TABLE OF CONTENTS}

I. INTRODUCTION ...................... 428

II. NOTES ON CONSTITUTIONAL JUSTICE IN ITALY . . . . . 429

III. THE ITALIAN CONSTITUTION (1948) . . . . . . . . . . . . 429

IV. THE CONSTITUTIONALLY REQUIRED AIMS OF PUNISHMENT $\ldots \ldots \ldots \ldots \ldots \ldots \ldots \ldots \ldots \ldots \ldots$

V. THE PRINCIPLE OF LEGALITY $\ldots \ldots \ldots \ldots \ldots \ldots \ldots \ldots$

VI. THE PRINCIPLE OF "CLARITY" $\ldots \ldots \ldots \ldots \ldots \ldots \ldots$

VII. THE PRINCIPLE OF MATERIALITY $\ldots \ldots \ldots \ldots \ldots \ldots \ldots$

VIII. THE HARM PRINCIPLE $\ldots \ldots \ldots \ldots \ldots \ldots \ldots \ldots \ldots$

IX. THE PRIVILEGE AGAINST SELF-INCRIMINATION: NEMO TENETUR PRODERE SEIPSUM . . . . . . . . .

$X$. THE PRESUMPTION OF INNOCENCE $\ldots \ldots \ldots \ldots \ldots \ldots$

XI. THE PRINCIPLE OF CULPABILITY: NULLA POENA SINE CULPA ..................

XII. THE PRINCIPLE OF "RECOGNIZABILITY"' OF THE

CRIMINAL CHARACTER OF THE OFFENCE AND THE NEED FOR CONGRUENCE BETWEEN CRIMINAL RULES AND MORAL (SOCIAL) RULES (KULTURNORMEN) . . . . . .

XIII. OTHER CONSTITUTIONAL PRINCIPLES APPLICABLE TO THE CRIMINAL LAW

XIV. A BRIEF COMMENT ON PARALLELS BETWEEN
DEVELOPMENTS IN CANADA AND ITALY $\ldots$

\section{INTRODUCTION}

A reading of the Canadian Charter of Rights and Freedoms, the leading decisions of the Supreme Court of Canada on the meaning of the Charter, and the works of commentators on these Canadian developments, prompts a comparison of Italian and Canadian law, and suggests that a liaison between Canadian and Italian scholars should be developed. The influence of a Bill of Rights on legislation can be very strong, and given that modern bills of rights have proven to be very similar throughout the western world, it is arguable that the laws themselves will in the future be more similar to one another in those countries which have entrenched constitutional protections.

In the field of criminal law, which is the focal point of this article, this process is readily observable. The criminal law of the continent has traditionally been quite different from the penal law as it has been shaped in the common law world. However, changes in the criminal law prompted by the need to satisfy constitutional requirements have resulted in criminal laws in continental countries and in North American jurisdictions which are becoming remarkably similar.' Canadian deci-

1. It is not surprising that the criminal laws of England and Scotland seem to differ more and more from the continental pattem; those countries have resisted the adoption of a criminal code. Conversely, criminal codes are in use in the U.S. and in Canada, as in all the continental countries of Europe. The absence of a written Bill of Rights furthermore increases the differences between the criminal laws of England and Scotland and those on the continent. 
sions, such as the Motor Vehicle Act Reference ${ }^{2}$ and Vaillancourt, ${ }^{3}$ have their pendants among the cases decided by the Constitutional Court of Italy, and principles derived under the Canadian Charter by some Canadian scholars accord with general principles ascribed to the Italian Constitution. For these reasons, it seems useful to explore the Italian doctrine of "constitutional-criminal law" as it has been developed since the 1950s. In the following pages, the Italian Constitution will be examined with a view to discerning the impact which it has had on general principles of criminal law. Most of these principles have a counterpart in the American criminal-constitutional law, but there is a comprehensive "constitutional approach" in Italy which forms a unique feature of the Italian jurisprudence. It is this which is perhaps of greatest interest to the Canadian reader. Excluded from this study are problems relating to criminal procedure, a topic which perhaps deserves a separate (and lengthy) discussion of its own. This is particularly so given the enactment of a new Italian criminal procedural code in 1988, which came into force in October, 1989.

\section{NOTES ON CONSTITUTIONAL JUSTICE IN ITALY}

The Italian Constitution came into force in 1948, following the end of the Fascist Regime. Within the broad constitutional framework is contained a Bill of Rights. Italian courts of general jurisdiction have no power to apply the Constitution directly, except in cases where the Constitution is used as a means of statutory interpretation. The only court which is vested with the power to strike down a law through the application of a principle derived from the Constitution is the Constitutional Court. That Court sits in Rome and is composed of fifteen judges, who are appointed by the President of the Republic (five members); by the Parliament (five members); and by the supreme bodies of the judiciary (five members). When a problem of constitutionality arises before a judge (at any level), he will remit the matter to the Constitutional Court, which will then adjudicate on the constitutionality of the statute. Whenever the Court concludes that the statute comports with the Constitution, the case is remitted and proceeds in the normal fashion. Where the statute is found to be unconstitutional it is regarded as having no effect as from the date of the decision. Finally, the Court can save the law by interpreting it in a way which does not clash with the constitutional protection. This is comparable to the practice of Canadian Courts in "reading down" potentially unconstitutional provisions.

\section{THE ITALIAN CONSTITUTION (1948)}

The Italian Constitution of 1948 contains some protections which directly concern the criminal law. First, Article 25(2) expresses the principle of legality: "No one can be punished under a law not in force at the time the alleged act was committed". Likewise, Article 27 provides that:

(1) Criminal responsibility is personal.

(2) An accused is not considered guilty until a definitive conviction is entered.

2. Ref. Re Section 94(2) of Motor Vehicle Act, [1985] 2 S.C.R. 1.

3. R. v. Vaillancoun, [1987] 2 S.C.R. 636. 
(3) Punishment cannot consist in treatments contrary to the sense of humanity and must be aimed at the re-education of the convicted.

(4) The death penalty is prohibited, except for those cases provided for in the military laws of war.

Some principles of criminal law are derived indirectly from the Constitution, either by virtue of specific provisions, or from the framework of the Italian Charter as a whole. Italian scholars have woven over the constitution a complex web of principles which govern the criminal law. This is a constitutional approach to the law of crimes, which proceeds to the point of defining the concepts of "crime" and "criminal responsibility". ${ }^{4}$ The Constitutional Court has sometimes backed the academics in this project, yet at the same time it has often shown some hesitancy along the path toward the "constitutionalization" of the criminal law. We will consider below most of the principles which have been developed in this way.

\section{THE CONSTITUTIONALLY REQUIRED AIMS OF PUNISHMENT}

As mentioned above, the issue of punishment is dealt with under Article 27 of the Constitution. The notion that punishment cannot be inhuman stems from the writing of Marquis Beccaria. Retribution, if not a goal of punishment, works at least to limit sentencing; punishment cannot be disproportionate to the guilt of the accused ${ }^{6}$ The only aim of punishment expressly dealt with by the Constitution is re-education, that is to say, re-socialization. While this objective may seem strange in a modern context, since scholars have cast serious doubts about the efficacy of punishment as a means for the re-socializing of offenders, ${ }^{7}$ one must keep in mind that the Italian Constitution was drafted over 40 years ago, at a stage when the "myth of re-education"' was prevalent. ${ }^{8}$ Moreover, there is still a considerable body of literature (especially on the continent), supporting re-socialization as a viable goal of punishment. ${ }^{9}$

From the Constitution one can indirectly derive another fundamental aim of punishment, namely general prevention. The Constitution describes the main values and interests of society. It allows the penal law to protect these interests, only if the threat of a penalty is likely to prevent infringements of those interests. The goal

4. Many books and articles in the Italian literature concem the interaction between the Constitution and the criminal law. One of the first contributions was by P. Nuvolone, Le leggi penali e la Costituzione, Milano, 1953. More recently, the most comprehensive constitutional approach to the criminal law has been attempted by F. Bricola, voce (item) Teoria generale del reato, Noviss. Dig. it. , Torino, 1973, 7 ff.

5. One remarkable exception has been the recent decision ("sentenza") n. 364/1988 (Constitutional Court) on mistake of law, in which a full doctrine of constitutional-criminal law was developed. On this case, see infra, note 11 .

6. See G. Fiandaca - E. Musco, Diritto Penale - Parte Generale, Bologna, 1985, 410.

7. See N. Walker, Punishment, Danger and Stigma - The Morality of Criminal Justice (Oxford: 1980) 54ss., for references.

8. E. Dolcini, La "rieducazione del condannato" tra mito e realta, Rivista italiana di diritto e procedura penale, 1979, 469.

9. G. Fiandaca - E. Musco, op. cit. note 6, 412-413. See also N. Walker, op. cit. note 7 at 55: "the evidence does not demonstrate what most people think it does: that treatment does not work [. . .]. The evidence does not justify abandoning such efforts, or the search for new techniques' . More recently, in the German literature: C. Roxin, Zur neueren Entwicklung der Kriminalpolitik, paper presented at Urbino, Italy, on June 15th, 1989. 
of punishment, then, is to prevent crime in order to protect the most important values and interests contained in the Charter. The criminal law is therefore a law of protection (Schutzrecht) $)^{10}$ and it is acceptable as long as it is apt and suitable as a protective device; that is, as long as it prevents offences. General prevention is thus an objective of punishment required by the Constitution. This approach receives confirmation in Article 13 which underlines the fundamental importance of personal liberty in the Italian Constitution. If liberty is important, then punishment, even if imposed by the state, is an evil which must be justified. One such justification can be general prevention; in fact, the interest of liberty is sacrificed, through the infliction of a penalty, only if that penalty is necessary to prevent further setbacks of interests protected by the Constitution - interests which can be comparable with, or even superior to, personal liberty. "It will be seen that from the recognition of the above mentioned aims of punishment, there follow some principles which concern the structure of the "offence" and the concept of "criminal responsibility".

\section{THE PRINCIPLE OF LEGALITY}

Article 25 of the Constitution deals expressly with the principle of legality: nulla poena sine lege. In Italy, scholars and courts are inclined to the view that this refers to "law" in a formal sense, i.e. laws enacted by the Parliament in due form. Other sources of law are not acceptable in principle. ${ }^{12} \mathrm{~A}$ problem is posed by those statutes which refer to an extra-legal provision (for example, those which require compliance with an administrative order, etc.). Such laws are considered to be compatible with the Constitution, as long as the legal structure is specific enough to describe the scope of the actus reus, or at least indicate with sufficient precision the content of the extra-legal provision referred to by the statute. ${ }^{13}$ As in Canada, in Italy there is a criminal code, and a further body of legislation on criminal matters. Every offence must be contained in statutory form; there is no "common law" or customary law whatsoever. It is therefore easier to apply the principle of legality in its strict sense in Italy than in some Anglo-American countries where a common law of crimes still exists, and where the ambit of the criminal law may still be expanded by the Courts. ${ }^{14}$

Additionally, in Italian criminal law "analogy" is prohibited. This means that it is not permissible to extend the scope of a statute to cases which are not contem-

10. The point has been deeply investigated in Germany more than in Italy. See H.-L. Günther, Die Genese eines Strafiatbestandes - Eine Einfihnning in Fragen zur Strafgesetzgebungslehre, Juristische Schülung, 1978, 8, 9 and 11.

11. See F. Bricola, supra, note 4, passim.

12. See recently M. Romano, Commentario sistematico del codice penale, I, Milano, 1987, sub art. 1, $32 \mathrm{ff}$.

13. Ibid., sub art. 1, 34-38.

14. This seems to happen more frequently in British jurisdictions: see H.L.A. Hart, Law, Liberty and Morality (Oxford: 1963) (rep. 1986), 6-12; P.R. Glazebrook, "How Long, then, is the Arm of the Law to be?", in 25 M.L.R. (1962), (for some English cases). See also G.H. Gordon, The Criminal Law of Scotland, (Edinburgh, 1976) (2nd ed.) 23-43 (for a discussion of the "declaratory power of the High Court" of Scotland); Ibid., First supplement to the 2nd ed., Edinburgh, 1984, ch. 1-32. See also, on the Scottish situation: W.A. Elliot, "Nulla poena sine lege", in Juridical Rev., 1956, 21-44; 1.D. Willock, Some Lessons on Khalig in Scolag, 1984, 124-126. Generally, on the problem: A.T.H. Smith, "Judicial Law Making in the Criminal Law", (1984) 100 L.Q.R., 46. 
plated by it, even in cases which raise issues analogous to those expressly contained in the law. Some scholars do admit the so-called analogy in bonam partem (in favour of the accused), which consists of the extension pro reo of the scope of a statute..$^{\text {is }}$ This principle makes possible the application of a justification or excuse beyond the narrow limits of the wording of the law. ${ }^{16}$ Analogy is forbidden in all cases if it is in malam partem. This is considered to be a fundamental tenet of Italian constitutional-criminal law. Even during the fascist era in Italy analogy was not allowed. By contrast, it was permissible in Nazi Germany, where the relevant statute (par. 2 of the StGB) recognized the possibility of expansions of criminal law according to "sound popular sentiment" (gesunde Volksempfindung). ${ }^{17}$ Finally, the principle of legality also embraces, of course, the principle of non-retroactivity of the law: law can only regulate future conduct. ${ }^{18}$

\section{THE PRINCIPLE OF “CLARITY”}

The principle of clarity in the criminal law is derived from the principle of legality. In fact, the idea of legality stems inter alia from the right of the individual not to be convicted without having the opportunity of knowing that the impugned conduct was illegal. This is because the offence must be imputable to the offender as a matter of his willful choice. ${ }^{19}$ The requirement that an individual must have the opportunity to become aware of the precise content of a prohibition implies that the law must not only be in force before the commission of the crime, but also its scope and meaning must be clear and precise enough to be understandable. It therefore seems obvious that the principle of legality implies the principle of clarity. ${ }^{20}$ Since a strict principle of legality is peculiar to the criminal law (at least in the Italian Constitution), it seems to follow that the requirement of clarity applies only to the law of crimes, and not to other kinds of law. ${ }^{21}$

The principle of clarity has a counterpart in North American law. The "voidfor-vagueness doctrine" 22 is the negative side of the same principle. In Italy, it is well-recognized, especially in the legal literature, as a basic tenet of Constitutional-criminal law..$^{23}$ The Constitutional Court seems to be quite reluctant, though, to strike down statutes because of their vagueness. This is probably a sign of the Court's reticence in interfering too deeply with the discretionary power of the Parliament. In one decision, nevertheless, the Court applied the principle in an interesting way. Article 603 of the Italian Penal Code set out the crime of

15. Eg. F. Antolisei, Manuale di diritto penale - Parte generale (ed. by L. Conti), Milano, 1985 (10th ed.).

16. See art. $50 \mathrm{ff}$ of the Italian Penal Code. Against this possibility, for example, P. Nuvolone, /I sistema del diritto penale, Padova, 1982. (2nd ed.), 131.

17. See H.L.A. Hart, supra, note 14 at 12.

18. See, among the American scholars, L.L. Fuller, The Morality of the Law, (Italian translation), Milano, 1986, 71-86.

19. See generally H.L.A. Hart, Punishment and Responsibility, Oxford, 1968 (REP. 1988), passim.

20. In Italy, see F. Bricola, La discrezionalità nel diritto penale, Padova, I. Milano, 1965; F.C. Palazzo, Il principio di determinatezza nel diritto penale, Padova, 1979.

21. More recently, see F. Bricola. Tecniche di tutela penale e tecniche alsernative di tutela, in M. De Acutis and G. Palombarini (ed), Funzioni e limisi del diritto penale. Altemative di tutela, Padova, 1984, 40-41.

22. See L.L. Fuller, supra, note 18 at $86-89$, who points out that the doctrine is usually confined to the field of criminal law (see note 21 of the text).

23. See notes 20 and 21 , supra. 
"plagiarism" (plagio). This made it a crime to reduce a person to a state of total subjection towards the offender. The Court explained that it was difficult to state the precise actus reus of this offence, since it was not easy to find any criminological category of conduct of the type described by the statute. ${ }^{24}$ This brought a new dimension to the vagueness doctrine in Italy. Not only is a law which is imprecise in the description of the offence considered unconstitutional, but so is a law which describes behaviour in a manner not adaptable to any known criminological type of conduct. ${ }^{25}$

This decision seemed to open the door to a full recognition of the principle of clarity by the Constitutional Court. But, very recently, at least two pronouncements of the Court make patent the unwillingness of the Roman judges to give too much scope for the application of the vagueness doctrine. ${ }^{26}$ In one of these cases, ${ }^{27}$ the Court drew a distinction between essential elements of the offence, which belonged to the core of the harmfulness of the crime, and accidental (or accessorial) elements of the crime, which add nothing to its unlawfulness. The principle of clarity, in the view of the court, applied only to the first class of elements and not to the second. The distinction may make sense in theory, but in practice it is sometimes hard to distinguish between essential and accidental ingredients. This is amply demonstrated by the case which was before the Court. The law under consideration makes it an offence to defraud the tax revenue system, but only when the evasion is of "considerable size" (misura rilevante). The Court pointed out that tax evasion is itself a crime, and the size of the evasion is not essential to the harmfulness of the offence. Therefore, even though the concept of "considerable size" could have been considered vague, this vagueness did not affect the overall constitutionality of the statute. Similar decisions render uncertain the future of the vagueness doctrine in Italy, even though its doctrinal development seems quite conspicuous.

\section{THE PRINCIPLE OF MATERIALITY}

Also derived from the Italian Constitution is the principle of materiality (materialitá). Article 25 of the Constitution speaks of the requirement of a deed (the term used is fatto). From this term, and from other textual considerations, it has been determined that the offence must consist of something "material": nullum crimen sine actione.$^{28} \mathrm{~A}$ person cannot be convicted if he or she did not perform a materi-

24. Corte Costituzionale, 9 Aprile-8 Guigno 1981, Sentenza n. 96, Rivista italiana di diritto e procedura penale, 1981, 1147-1166, with observations by M. Boscarelli, A proposito del "principio di tassativitá"', ivi, 1147-1151.

25. G. Marinucci, Fatto e scriminanti - Note dommatiche e politico - criminali, Rivista italiana di diritto e procedura penale, 1983, 1180, 1209, 1210; F. Bricola, Rapporti tra dommatica e politica criminale, Rivista italiana di diritto e procedura penale, 1988, 3, 18-20.

26. Corte Costituzionale, 9-18 Gennaio 1989, Ordinanza n.11, Gazzetta Ufficiale della Repubblica Italiana, 25-1-1989, 1 Serie spec., n. 4. In this case, the general statute prohibited the manufacture of toy-pistols without a red stopper at the tip of the barrel. Some courts extended the application of the statute to simple possession by private individuals. But possession does not appear to be the actus reus described in the statute. The statute probably should have been declared void for vagueness. But the Constitutional Coun tersely rejected such a solution.

27. Corte Costituzionale, 16 Maggio 1989, Sentenza n. 247, Foro italiano, 1989, 1685-1701, with a comment by G. Insolera - M. Zanotti, $L$ 'intervento interpretativo della Corte Costituzionale sulle ipotesi di frode fiscale ex art. 4 n. 7, della 1 . 516 del 1982, ivi, 1686-1695.

28. See e.g. F. Mantovani, Diritto penale - Parte generale, Padova, 1979, 147-181. 
ally observable act. Similarly, in Anglo-American law, a so-called "true" criminal offence must be composed of an actus reus, together with the mens rea. ${ }^{29}$ Certainly under Canadian law there appear to be no exceptions to the requirement of an actus reus. In Italy, this means that the Constitution prohibits punishment of a mere thought: cogitations poenam nemo patitur. ${ }^{30}$ This is confirmed by the right of free conscience and free expression of thought, both of which are mentioned as fundamental liberties of the individual in the Italian Constitution.

The principle of materiality confronts other types of offences which may be considered to be in conflict with it. Among these are crimes of omission. How is it possible to find the requisite "materiality" in a negative act such as an omission? Over the years, lawyers have endeavoured to reconcile the idea of omissions with the concept of action (actio), and in the course of doing so, some strange theories have been developed. Von Luden, a German scholar, thought that an omission was culpable because of the conduct which the offender had in fact performed, instead of that which was required by law. The same idea had been considered by some theologists at the time of St. Thomas Aquinas. But Aquinas himself, and the plurality of modern criminal lawyers, have replied that the conduct performed in place of that which was required is not essential to the concept of omission. An omission is the non-performance of an act which the offender was required to perform (non facere quod debetur). ${ }^{31}$ It is not obvious, then, how this negative behaviour can be compatible with the principle nullum crimen sine actione. ${ }^{32}$

There is a solution, nevertheless, to this problem. Omission is a normative concept, that is to say, an omission is only understandable if one has in mind an obligation to act (i.e. the required act). From a normative point of view, an omission is behaviour which has a "normative materiality" of its own. If a person becomes aware of an impending treasonist act and does not report it to the appropriate authorities, that person commits the crime of misprision of treason..$^{33}$ This omission has a material significance from a normative point of view, even though it does not have any significance from a purely physical standpoint.

The main function of the principle of materiality is to protect the individual from punishment for a mere thought; punishing for omissions does not contravene this rationale. This becomes obvious in the case of so-called non-genuine omission crimes, ${ }^{34}$ such as where an omission may cause serious physical harm to another. This might occur, for example, where a mother, under a duty to provide for her child fails to do so (with fatal consequences).

29. In the English literature see: G. Williams, Textbook of Criminal Law, London, 1983 (2nd ed.), $146 \mathrm{ff}$.; Smith and Hogan, Criminal Law, London, Edinburgh, 1988, (6th ed.), 33-54. In the American literature see: R.M. Perkins - R.N. Boyce, Criminal Law, Mineola (N.Y.), 1982 (3rd. ed.), $605 f f . ;$ W.R. La Fave-A.W. Scolt Jr., Handbook on Criminal Law, St. Paul, Minn., 1972, 177-181.

30. In the German literature see, on the topic, P. Stechmann, Enrwicklung und Bedeutung des Satzes "Cogitationis Poenam Nemo Patitur" (DISS.) Hamburg, 1976.

31. See my book II reato omissivo proprio - I - Profili introduttivi e politico criminali, Padova, 1988, 151-182, for further reference and a broader discussion on this topic.

32. See G. Marinucci, /l reato come azione - Critica di un dogma. Milano, 1971, 178; F. Mantovani. supra, note 28 at 157; F. Bricola, supra, note 4 at 71 ; N. Mazzacuva, Il disvalore d'evento nell illecito penale, Milano, 1983, $149 \mathrm{ff}$.

33. See R.M. Perkins \& R.N. Boyce, supra, note 29 at 506.

34. On the distinction between genuine crimes of omission and non-genuine crimes of omission see A. Cadoppi, supra, note 31 at 67-150. 
There is, then, a general compatibility between the principle of a materiality and crimes of omission. However, there are some instances when one might say that crimes of omission are not consistent with the principle of materiality, as for example where the omission is one of "pure disobedience" and there is no material outcome arising from this violation of the law. ${ }^{35}$ Similarly, when the omission is nothing more than an excuse to punish the status or "position" of the offender, (sometimes referred to as "situational absolute liability"), there is no materiality in the behaviour of the accused: here the accused may be held responsible for the act of another. ${ }^{36}$ In these cases one could not speak strictly of an "omission" on the part of the accused, because there is no actus reus at all.

\section{THE HARM PRINCIPLE}

The harm principle was developed, in the Anglo-American legal-philosophical tradition, by John Stuart Mill; ${ }^{37}$ in a modern context it has been further developed by the work of the American scholar Joel Feinberg. ${ }^{38}$ In Italy, this idea has been sharpened in the last century, prompted by the work of the German scholar, Birnbaum. He wrote about the "legal good" (Rechtsgut; bene giuridico), which constitutes an "interest" which has to be protected by the criminal law. It is only permissible to punish behaviour if it causes harm to a "legal good". The concept of the legal good replaced the concept of right, which was considered to be the only legitimate subject of legal protection up to the first half of the nineteenth century. The change from the notion of "right" to the notion of "legal good" was important because it permitted the punishment of behaviour which offended interests not belonging to individuals, but to society at large. ${ }^{39}$ The concept of "legal good" is still fashionable in the criminal law context, and this topic continues to generate scholarly works in continental Europe.$^{40}$ But it is still difficult to identify with sufficient precision the scope of this notion. Can a "legal good" be a vague "feeling"' of the community? Can it include the common notion of public (or even private) morality? Can it be the devotion to a particular religion?

One successful attempt at focusing on the precise dimensions of the concept of the legal good can be found in the work of Professor Franco Bricola, ${ }^{41}$ who

35. F. Mantovani, supra, note 28 at 157.

36. See also, in the Italian literature, A. Cadoppi, op. cir. at 624-26. See also, in the English literature, P.R. Glazebrook, Situational Liability, in Reshaping the Criminal Law, Essays in Honour of Glanville Williams, London, 1976, $114 \mathrm{ff}$.

37. J.S. Mill, On Liberty, in Utilitarianism, On Liberty and Considerations on Representative Government, cd. by H.B. Acton, London and Melboume, 1977 (reset 1984), 69, 78.

38. J. Feinberg, The Moral limits of the Criminal Law; 4 vols New York, Oxford, 1984-1988, of which vol. 1 is named Harm to Others (1984). See also, less recently, H.L.A. Hart, supra, note 14 at 4 and passim.

39. For all these and more details on the concept of "bene giuridico"' see, among others, E. Musco, Bene giuridico e tutela dell 'onore, Milano, 1974; G. Fiandaca, Il "bene giuridico" come problema teorico e come criterio di politica criminale, in G. Marinucci and E. Dolcini (ed.), Dirino penale in trasformazione, Milano, 1985, 139: F. Angioni, Contenuto e funzioni del concetto di bene giuridico. Milano, 1983.

40. See, in the German literature, H.H. Jescheck, Lehrbuch des Strafrecht, Berlin 1978 (3rd ed.) 5-7; 203-208. In the Spanish literature, e.g., G. Quintero Olivares, Derecho Penal - Parte General, Barcelona, 1986, 85-92.

41. F. Bricola, supra, note 4 at $15 \mathrm{ff}$, and passim. 
analyzed the Italian Constitution and gave constitutional legitimacy to the harm principle. At the same time, he limited the number of legal goods to those contained in the Constitution, and in particular to those which were comparable (in hierarchic value) to the right of the individual to personal liberty. This meant that the state can limit the personal liberty of the individual only if this was necessary to protect a constitutional interest whose value is at least comparable to the value of the right which has been limited. An interest of society not contained among the interests directly (or indirectly) protected by the Constitution could not be the object of protection through the criminal law. A statute designed to protect such an interest would be contrary to the Constitution and therefore liable to be struck down by the Constitutional Court. The same could happen, a fortiori, to a criminal statute not designed to protect any interest at all, or designed to protect only very indirectly some kind of interest. ${ }^{42}$

This doctrine has been extensively discussed in the Italian juridical debate. It is designed to limit sharply the extension of the criminal law, which is rightly considered an extrema ratio, to which the state can resort only if it is not possible to do otherwise. In the jurisprudence of the Italian Constitutional Court, the principle has only been recognized in obiter dicta and it has had little influence in specific cases. Yet, this idea has been referred to with increasing frequency, ${ }^{43}$ and it may be that in the future the Court will make practical use of this doctrine.

By contrast, some scholars seem to have adopted this doctrine, or, at least, they have recognized its importance in the development of a constitutionally-oriented notion of crime. Others have criticized it, not because of its faulty theoretical basis, but because, in practice, it is virtually unavailable as a defence. They have observed that it is very difficult to find an interest (or a "legal good") which is not contained in the Constitution, or at least not implied by it. This means that almost all criminal statutes can be considered, if a Court is so inclined, as aimed to protect a constitutional interest. ${ }^{44}$ As a consequence, it would be easy for the Constitutional Court to save a criminal statute, claiming that it protects an interest implied within the Charter. Obviously this illustrates the weakness of the theory, but of course, it is difficult to find any juridical doctrine which does not create problems of application in practice. Moreover, it is very difficult to reduce the discretionary power of a Constitutional Court by means of a theoretical doctrine.

More recently, in order to narrow the scope of the interests which are liable to protection under the criminal law, it has been suggested that what should be required is that the interests have not only a constitutional dimension, but also that there be a "cultural" recognition of that interest by the public. In other words, the interests to be protected would be those regarded by the general populus as sufficiently important. ${ }^{45}$ This matter will be pursued below.

42. The latter case raises the problem of the so-called "dangerous offenses" (reati di pericolo), crimes which give rise to a mere probability (or possibility) of harm to a legal good. There has been an extensive debate on their legitimacy in Italy: see, recently, G. Grasso, L anticipazione della tutela penale: $i$ reati di pericolo e i reati di attentato, Rivista italiana di diritto e procedura penale, 1986, 686.

43. For example Corte Costituzionale, 25 maggio 1987, sentenza n. 189, Foro italiano, 1987, 1, 265 , 269-270; ID., 24 marzo 1988, Sentenza n. 364, Foro italiano, 1988, 1, 185, 1405.

44. See the authors cited at note 39 , supra.

45. See A. Cadoppi, supra, note 31 at 586-607. 


\section{THE PRIVILEGE AGAINST SELF-INCRIMINATION: NEMO TENETUR PRODERE SEIPSUM}

Another principle derived from the Constitution is the privilege against selfincrimination: nemo tenetur prodere seipsum. This doctrine is of primary importance in the context of criminal procedure, but it also affects the substantive criminal law. A statute can be found in conflict with this principle if it requires a person to confess to the commission of a crime. For example, consider a tax statute which requires the taxpayer to file a return describing his previous financial transactions. If he has committed a crime through one of his financial manoeuvres, he would, in theory, be required to incriminate himself. This conflict between the privilege and the requirements of the criminal statute could be resolved in different ways, but in my opinion such a statute should be declared unconstitutional, at least in those instances where it infringes the principle nemo tenetur prodere seipsum..$^{46}$ The recent Italian literature agrees with this view ${ }^{47}$ but the judiciary seems not to have a clear position on this question. Some courts do recognize the privilege as having substantive criminal law importance; others are more reluctant to adopt this position, even though they may acquit the accused on different, and sometimes uncertain, grounds. ${ }^{48}$

\section{$X$. THE PRESUMPTION OF INNOCENCE}

The presumption of innocence is expressed directly in the Italian Constitution. It is a principle which is of mainly procedural interest, but it too affects substantive criminal law. Statutes which create problems in light of this doctrine are those in which the accused must prove the existence of a lawful excuse. For example, art. 707 of the Italian Penal Code makes it an offence to possess house-breaking instruments, if the possessor (a person previously convicted for crimes against property) does not justify the retention of those objects. Interestingly, the Constitutional Court has not yet declared this provision unconstitutional, ${ }^{49}$ and Italian scholars have not deeply investigated the problem from the point of view of the presumption of innocence. ${ }^{50}$ Some recent Canadian cases on this subject are more instructive, even though they may send out some conflicting signals. ${ }^{51}$

46. A. Cadoppi, II reato omissivo proprio - II-Profili dogmatici comparatistici e de lege ferenda, Padova, 1988, 757-759. See, in the american literature, G. Hughes, "Criminal Omissions", 67 Yale Law J. (1957), 590, 612; H.G. Balter-J.R. Guidoti, Tax Fraud and Evasion, 1983 Suppl. (5th ed.), BostonNew York, 1983, s. 11-4, (note 89-4 of that text).

47. M. Zanotti, Nemo tenetur se detegere: profili sostanziali, Rivista italiana di diritto e procedura penale, 1989, 174-213.

48. See M. Zanotti, ibid., passim.

49. A. Pizzonusso, note to Corte Costituzionale, 30 Ottobre 1975, Sentenza n. 236, Foro italiano, 1976, I, 15.

50. With some important exceptions: e.g. F. Bricola, supra, note 4 at $89 \mathrm{ff}$.

51. See, recently, B. Ziff, La Charter canadese dei diriti e delle libertà e l'onere della prova nel processo penale: nozioni fondamentali e recenti sviluppi, Foro italiano, 1989 (forthcoming) comprehensive comment to R. v. Holmes, [1988] I S.C.R. 914; R. v. Whyte [1988] 2 S.C.R. 3. 


\section{THE PRINCIPLE OF CULPABILITY: NULLA POENA SINE CULPA}

The most remarkable developments in constitutional/criminal law in Italy are those in the field of the principle of culpability (nulla poena sine culpa). Scholars have written a considerable amount in the last twenty years on this topic, and their efforts have now achieved some success through a recent decision of the Constitutional Court, in a case which deals with the issue of mistake of law.

The first constitutional hurdle stems from the fact that the Italian Constitution does not expressly recognize the principle of culpability. What the Charter says, simply, is that "penal responsibility is personal". In the opinion of the early commentators on the Constitution, this meant only that one person could not be held responsible for the act of another. ${ }^{52}$ Subsequently, the literature began to interpret more systematically the Constitution, and the above-mentioned phrase was read in conjunction with that part of Article 27 of the Constitution which identifies "re-socialization" as a goal of punishment. If a penalty must tend to re-socialize the offender, it means that the offender needs re-socialization, and that he has shown indifference to social values through the commission of a crime: put another way, he has demonstrated blameworthiness (a sort of mens rea towards the values of the community embodied in the law), which demonstrates his culpability. ${ }^{53}$

But this is just the first step along the path toward the full recognition of a principle of culpability. As demonstrated in the recent decision of the Constitutional Court, ${ }^{54}$ the entire Constitution leads to the conclusion that nulla poena sine culpa is a basic tenet of the Italian Constitutional-Criminal Law. In fact, the principle of legality itself, and the principle of clarity which is deduced therefrom, implies that a person must have the possibility of knowing, before performing the act, that what he or she is doing is a crime. This means that the commission of a crime is considered by the Constitution as the "choice" of the offender, who knows (or, at least, has an opportunity to know) that he or she is breaking the law. If this is true, then it would be absurd to punish a person who is not blameworthy in this way.

Another fundamental argument for the recognition of the principle of culpability is that the Italian Constitution views the human being as the most important object of protection. The person, with his or her dignity and freedom of choice, has a central role in the framework of the Constitution. It would be inconsistent with such a philosophical approach to the Charter to punish a person who is not responsible or blameworthy for what he or she has done. ${ }^{55}$

The principle of culpability, then, has been fully recognized as a fundamental tenet of Italian Constitutional-Criminal Law, derived from the overall framework of the Charter. This principle means, of course, that there should be a prohibition on any kind of strict (or "absolute") liability (responsabilitá oggettiva)..$^{56}$ However, it has yet to be ascertained to what extent an offender must be culpable for the commission of a crime. Specifically, it is not yet clear whether there are some

52. See e.g. P. Nuvolone, supra, note 4 at $31 \mathrm{ff}$.

53. D. Pulitano', item Ignoranza (dir. pen.). Enciclopedia del diritto, vol. XX, Milano, 1970, 23, 36; F. Bricola, supra, note 4 at 54.

54. Corte Costituzionale, Sentenza n. 364, supra, note 43, passim.

55. Corte Costituzionale, Sentenza n. 364, supra, note 43 at 1410.

56. See on the matter A.M. Stile (ed.), Responsabilità oggettiva e giudizio di colpevolezza, Napoli, 1989. 
elements of an offence which may be ascribed to the accused without any culpa on his part. The Constitutional Court seems to have limited the culpability requirement to the so-called "essential elements" of the crime. Residual strict (or absolute) liability could remain with respect to the so-called "accidental elements" of the crime (for example, aggravating circumstances).$^{57}$ In the literature, it has been suggested that culpability should be required for every element (whether accidental or essential) of the crime. ${ }^{58}$ The most interesting feature of the Constitutional developments concerning the principle of culpability is that it is considered to cover not only the actus reus of the offence but also knowledge of the unlawfulness of the act itself.

In March, 1988, the Constitutional Court decided that Article 5 of the Italian Criminal Code was unconstitutional ${ }^{59}$ That statutory provision dealt with mistake of law and strictly applied the maxim ignorantia legis non excusat. The Court pointed out that the principle of culpability implies that the offender must know the illegality of his act, or at least should have known it. This is because if he acts without having any opportunity to become aware of the harmfulness and unlawfulness of his behaviour, he is not truly blameworthy; he did not intend, nor could he be taken to intend, to break the law, nor did he intend, nor could he be taken to intend, to harm anyone. To punish such a person would be intolerable in view of the fundamental tenets of the Constitution.

Of course, the lack of knowledge of the law must be excusable; that is, it must have been impossible (or almost impossible) for the offender to know the law, so that his ignorance or mistake of law is effectively "unavoidable". In such a case, he will not be culpable and therefore he will not be punishable.

In practice, such an excusable ignorance of the law is less likely to occur in cases where the offence is malum in se; in those instances, it will be difficult for the accused to show the unavoidability of his mistake. Correlatively, it is among the offenses which are mala prohibita that the defence will more likely be successful.$^{60}$ It is a matter for the lower court to decide, in any given case, if the mistake is excusable or not. Acting on this relatively new doctrine, the courts have at times acquitted on this ground, particularly with regard to petty offenses and violations which are minimally harmful to the interests of the State or individuals. ${ }^{61}$

The pronouncement of the Constitutional Court in relation to this matter has been enthusiastically received by the scholarly community; almost all of the writing to

57. Corte Costituzionale, Sentenza n.364 (note 43), 1403. More recently, Corte Costituzionale, 30 novembre 1988. Sentenza n. 1085. Rivista trimestrale di diritto penale dell 'economia, 1989, 232, 239-240.

58. D. Pulitano', Una sentenza storica che restaura il principio di colpevolezza, Rivista italiana di diritto e procedura penale, 1988.

59. Corte Costituzionale, Sentenza, n. 364, supra, note 43: the pronouncement has been delivered by J. Renato Dell'Andro, a well known professor of criminal law.

60. The arguments are developed in the long Sentenza cited at note 43, passim.

61. For example, the owner of a house built a garage in the backyard of his home, without getting the permission from the mayor, because he thought that it was not necessary: he was aquitted by Pretura Reggio Emilia, 28.9.1988 (pret. Mazzei), Rivista trimestrale di diritto penale dell 'economia, 1989. 273-276, with a note by $\mathrm{A}$. Cadoppi. Other cases are very similar, involving mala prohibita quite inconsistent with the harm principle. 
date has praised the initiative of the Roman judges. ${ }^{62}$ Indeed, for many years, limits on the scope of the archaic maxim ignorantia legis non excusat ${ }^{63}$ had been advocated in the Italian literature. And in many other jurisdictions in continental Europe there now exist statutory enactments which excuse particular kinds of mistakes of law. ${ }^{64}$ In short, the Constitutional Court demonstrated the courage to put Italy in line with other countries with juridically comparable traditions.

\section{THE PRINCIPLE OF "RECOGNIZABILITY" OF THE CRIMINAL CHARACTER OF THE OFFENCE AND THE NEED FOR CONGRUENCE BETWEEN CRIMINAL RULES AND MORAL (SOCIAL) RULES (KULTURNORMEN)}

There is a passage in the decision of the Constitutional Court concerning mistake of law that could be of great importance in the future development of a constitutional approach to criminal law. The Court pointed out that penal laws must be understood by the offender as these relate to the moral laws accepted by society. The Court referred to this as the "principle of recognizability". The offence must be "recognizable" by the actor, in the sense that he or she knows that the behaviour is contrary to law, because it also conflicts with social morality. ${ }^{65}$ This principle not only leads to the limitation of the maxim ignorantia legis neminem excusat, it also requires the legislator to draft criminal statutes so that proscribed behaviour is not merely contrary to law, but also violates social mores generally accepted by the public. This is now a Constitutional requirement ${ }^{66}$ It implies that if a crime, as defined by a statute, is not also considered to be a wrongful deed by the moral (or perhaps more correctly the "cultural") norms of the society at large (Kulturnormen), ${ }^{67}$ the statute would be unconstitutional.

62. See G. Fiandaca Principio di colpevolezza ed ignoranza scusabile della legge penale: "prima lettura" della sentenza n. 364/1988, Foro italiano, 1988, I, 1385; Pulitano', supra, note 53; F.C. Palazzo, Ignorantia legis: vecchi limiti ed orizzonti nuovi della colpevolezza, Rivista italiana di diritto e procedura penale, 1988, 920 ss; T. Padovani, L'ignoranza inevitabile sulla legge penale e la declaratoria d'incostituzionalità parziale dell'art 5 c.p., Legislazione penale, 1989, 449: P. Patrono, Problematiche attuali dell 'errore nel diritto penale dell'economia, Rivista trimestrale di diritto penale dell 'economia, 1988, 87; L. Stortoni, L'introduzione nel sistema penale dell 'errore scusabile di diritto: significati e prospettive, Rivista italiana di dirito e procedura penale, 1988, 1330; A. Lanzi, L'esimente dell 'errore su norme tributarie fra la giurisprudenza di legitrimità e quella costituzionale, Rassegna tributaria, 1988, I, 334; A. Cadoppi, La nuova configurazione dell'art. 5 c.p. ed i reati omissivi propri, in A.M. Stile (ed.), supra, note 56 at 227. The Minister of Justice has himself, as a criminal law professor, favourably commented on the decision: $G$. Vassalli, $L$ 'inevitabilità dell ignoranza della legge penale come causa generale di esclusione della colpevolezza, Giur. cost., 1988, II, 3.

63. E.g. F.C. Palazzo, L'errore su legge extrapenale, Milano, 1974; D. Pulitano', L'errore di diritto nella teoria del reato, Milano, 1976.

64. See H.H. Jescheck, supra, note 40 at 378; ID., L errore di diritto nel diritto penale tedesco e italiano, Indice penale, 1988, 185, 200-203. See also G. Vassalli, op. cit. (note 61), 4-5. In the anglo-american literature, see, for a compative law perspective, P.K. Ryu and H. Silving, "Error Juris: A Comparative Study", 24 Univ. of Chicago Law Rev. (1957), 421; A.T.H. Smith, "Error and Mistake of Law in Anglo-American Criminal Law", Anglo-American Law Rev., 1985, 3. For a comparison between German and American development of the doctrine: G. Artz, "Ignorance or Mistake of Law", 24 Am. Joum. Comp. Law (1976), 646; for comments on this paper see J. Hall, "Comment on Error Juris", ivi, 680; P.K. Ryu and M. Silving, "Comment on Error Juris", 689.

65. Corte Costituzionale, Sentenza n. 364, supra, note 43 at 1405.

66. lbid.

67. See M.E. Mayer, Rechtsnormen und Kulturnormen (Breslau, 1903), rep. Darmstadt, 1965. 
This doctrine has recently been developed in the literature.$^{68}$ It has been suggested that it would be possible to test the congruence between legal (penal) and moral norms, by means of surveys designed to measure the scale of seriousness of deviant behaviour. ${ }^{69}$ There is an abundance of research in this field and it seems that such a methodology could be practicable. ${ }^{70}$ If the public is not substantially in agreement about the "criminal character" of certain behaviour, that behaviour should not be deemed criminal by the law. "Such a consensus is, after all, a condition for the efficacy of the criminal law as a means of general prevention. In fact, if common morality does not consider an act to be wrongful, it is unlikely that people would obey a law which labels such behaviour as criminal. ${ }^{72}$

Finally, the principle does not imply the converse, that cultural norms alone require the existence of new criminal prohibitions. In other words, it does not mean that whenever public opinion considers behaviour to be immoral, that behaviour must be deemed as a crime. This would lead to the punishment of immorality as such, and would not be accepted in a modern, democratic, and liberal state. ${ }^{73}$

\section{OTHER CONSTITUTIONAL PRINCIPLES APPLICABLE TO THE CRIMINAL LAW}

There are, in fact, a number of other values, principles, and rights pertaining to the criminal law which may be derived from the Constitution. For example, the equality principle renders unconstitutional any law which does not treat people equally. This principle has been applied by the Constitutional Court to strike down numerous criminal statutes. Moreover, many civil liberties, such as freedom of conscience, of religion, of thought, of assembly, etc., are recognized in the Italian Con-

68. A. Cadoppi, supra, note 31 at $371-738$. See the references to continental and anglo-american literature, passim.

69. A. Cadoppi, ibid. at 695-706.

70. The first comprehensive work on the issue was written by T. Sellin, M. E Wolfgang, The Measurement of Delinquency, New York, 1964. Now, there is an almost endless bibliography on the subject. See, for bibliographical research in the Italian language. T. Delogu-M. C. Giannini, L'indice di criminalità di Sellin e Wolfgang nella reoria generale della misurazione di gravità dei reati. Milano, 1982, 439-458. For a fruitful Italian research on the point see E.U. Savona, Criminalità o devianza? Confronto tra reazione "ufficiale" e reazione dell'opinione pubblica, Sociologia del diritto 1980 , n. 3, 107. In the English literature, see, for a recent and conspicuous work, N. Walker and M. Hough (ed.), Public Atritudes to Sentencing - Surveys from Five Countries, Aldershot, 1988.

71. The justification for this principle comes from the principle of legality, from the principle of culpability, and from the aims of punishment derived from the Italian Constitution: see Corte Costituzionale, Sentenza n. 364, supra, note 43 at 1405 and passim. See also my book (supra, note 31), 408-454 and passim, with further references.

72. See, in the anglo-american literature, e.g. J. Andenaes, The Moral or Educative Influence of Criminal Law (1971), in ID., Punishment and Deterrence (Ann Arbor, Mich.: 1974) at 110 and 125; S. Kadish, "Some Observations on the Use of Criminal Sanctions in Enforcing Economic Regulations", (1963) 30 U. Chi. L. Rev. 423 at 437. See also L.L. Fuller, supra, note 18 200ff; ID., "Morals and The Criminal Law". (1942) 32 Journ. Crim. Law and Crim. 624 at 629-630. See also, in the German literature, H.H. Jescheck, Das neue deutsche Strafrecht in der Bewährung (1980), Italian translation (f. Molinari). Indice penale, 1981. 5, 13. In the italian literature, among many others. A. Pagliaro, Verifica empirica dell 'effetto di prevenzione generale, Rivista italiana diritto e procedura penale. 1986, 353. 354ff; C.E. Paliero, "Minima non curat preator" Ipertrofia del diritro penale e decriminalizzazione dei reati bagatellari, Padova, 1985, 217 (and 357).

73. Among hundreds of scholars, see H.L.A. Hart, supra, note 14. See recently, in the ltalian literature, G. Fiandaca, Problematica dell'osceno e tutela del buon costume, Padova, 1984. 
stitution. Again, the Court has declared unconstitutional many statutes which have infringed such Constitutional rights.

But these values, principles, and rights are not peculiar to the criminal law. By contrast, the principles outlined above have been directed largely to the law of crimes and do not apply as extensively to administrative violations or civil torts. The separate "image" of crime has taken on a clearer and quite distinct shape from other types of law. Such a portrait flows from the systematic interpretation of the Italian Constitution. ${ }^{74}$

\section{A BRIEF COMMENT ON PARALLELS BETWEEN DEVELOPMENTS IN CANADA AND ITALY}

As suggested at the beginning of this paper, the Canadian Charter of Rights and Freedoms could ultimately give rise to a comprehensive doctrine of ConstitutionalCriminal Law comparable to that found in the Italian Constitution. Indeed, from many of the sections in the Canadian Charter, and especially from the broadlytermed Section 7, one could easily extract the same principles that have been derived from the Constitution of Italy. Canadian scholars have started to develop a sensible interpretation of the Charter in relation to its influence on the criminal law. ${ }^{75}$ The Supreme Court itself, in recognizing (to a certain point) principles such as the presumption of innocence, ${ }^{76}$ and especially the principle of culpability, ${ }^{77}$ has shown a laudable willingness to give the Charter an expansive interpretation. The Motor Vehicle Reference, in which the Supreme Court concluded that substantive review of criminal law statutes was contemplated by the Charter comports with the approach taken in Italy. The importance of subjective criminal liability, recognized in part in Vaillancourt in the context of murder, again illustrates the compatibility of Italian and Canadian Constitutional jurisprudence. Especially in relation to the principle nulla poena sine culpa, the paths of the Canadian and Italian Supreme Courts seem to run parallel, toward a vision of a new criminal law, in which "fundamental justice"' will eventually prevail.

74. For a fundamental discussion of the issue see F. Bricola, supra, note 4.

75. See I. Grant, “'R. v. Vaillancourr: The Constitutionalization of Mens Rea” (1988) 22 U.B.C. L. Rev. 369; J.D. Whyte, “Annotation to Re Motor Vehicle Act, 43 C.R. (3d) 292; S.J. Usprich "Felony Murder and Far Beyond", 60 C.R. (3d) 332; P. MacKinnon, "Note to Vaillancourt v. The Queen" (1988) 67 Can. Bar Rev. 350; I. Grant and A.W. MacKay, "Constructive Murder and the Charter: In Search of Principle" (1987) 25 Alta. L. Rev. 129; D. Stuart, "Progress on the Constitutional Requirement of Fault", 64 C.R. (3d) 354; L. Viau, "Les éléments essentiels et la charge de la preuve des infractions criminelles at réglementaires" (1988) 33 McGill L. J. 555; A. Manson, "Annotation to Re Motor Vehicle Act", 48 C.R. (3d) 295; A.M. Linden and P. Fitzgerald, "Recodifying Criminal Law" (1987) 66 Can. Bar Rev. 529; B.P. Archibald, "The Constitutionalization of the General Part of the Criminal Law" (1988) 67 Can. Bar Rev. 403; B. Ziff, supra, note 51.

76. See B. Ziff, supra, note 51.

77. On $R$. v. Vaillancourt, supra, note 3, see, in the Italian literature, my note Colpevolezza e principi costituzionali: le recenti "coraggiose avventure" della Corte Suprema Canadese, Foro italiano, 1989, IV, 250. 